\title{
Life course social roles, women's health in mid-life and agency as quality
}

Anne McMunn, Mel Bartley \& Diana Kuh

\section{ABSTRACT}

Data from a prospective British birth cohort study showed that women who were childless, lone mothers or full-time homemakers between the ages of 26 and 54 were more likely to report poor health at age 54 than women who occupied multiple roles between these ages. To explain this finding we developed and tested a theory of role quality based on the concept of agency by drawing on Giddens' theory of structuration and Doyal \& Gough's theory of human needs. According to our theory, the patriarchal structuration (drawing on Giddens' term) of work and family roles provides both limitation and opportunity for the expression of agency. Doyal \& Gough's theory of human needs was then used to identify the restriction of agency as a possible influence on health. This theory of role quality was operationalised using a measure of work (paid and unpaid) quality at age 36 and a measure of work and family stress between ages 48 and 54 . The relatively poor subjective health in mid-life of lone mothers was explained by work and family stress and adult social class. In contrast, the poor health in mid-life of long-term homemakers and childless women was less easily explained. Homemaker's excess risk of reporting poor health at age 54 remained strong and significant even after adjusting for role quality and socioeconomic indicators, and childless women were at an increased risk of reporting poor health despite the social advantage inherent in attaining educational qualifications and occupying professional or managerial occupations. This study highlights the need to develop measures of role quality specifically designed to capture agency aspects of social roles.

Abstract word count: 277 
Key words: UK, women's health, social roles, agency, life course

Full word count: 7,593

\section{INTRODUCTION}

Existing research on relationships between social roles and health generally lacks a theoretical basis and relies on cross-sectional data. In this paper we briefly review some of this work and then draw upon Giddens' theory of structuration, as well as Doyal \& Gough's theory of human needs, to develop a theory of role quality that focuses upon the concept of agency. Prospective cohort data are used to examine longitudinal relationships between life course social roles and subjective health in mid-life, and to investigate the extent to which indicators of agentic role quality, as developed in the early part of the paper, mediate these relationships.

\section{Social roles and health: a brief review}

Early work into the effects on women's health of increasing labour market participation in the face of continued female responsibility for childcare and housework was characterized by two opposing theoretical models. Role strain was first introduced by Goode (1960) as a general theory in which social actors are continually seeking to reduce the demands of their many, and sometimes conflicting, roles. Conversely, role enhancement theorists (Marks, 1977; Sieber, 1974; Thoits 1986) proposed that health is enhanced by participation in all socially valued activities, such as marriage, parenthood and employment. Overall, empirical support for the role enhancement hypothesis has been fairly consistent in that women who have enacted more roles have generally been found to be mentally healthier than those who have enacted fewer roles (Barnett \& Hyde, 2001; Feld, 1963; Hibbard \& Pope, 1991; Macran, Clarke, Sloggett \& Bethune, 
1994; Repetti, 1998; Repetti, Matthews \& Waldron, 1989; Verbrugge, 1983; Waldron, Weiss \& Hughes, 1998).

Work examining relationships between roles and health eventually shifted away from counting the total number of roles enacted, towards investigating aspects of role quality (Crosby, 1987). Several potential benefits of occupying multiple roles have been raised, such as increased access to social contacts (Moen, Dempster-McClain \& Williams, 1989; Sieber, 1974; Verbrugge, 1983, 1987), financial resources, self-esteem, and prestige (Marks 1977, Sieber 1974), power (Thoits 1987, Marks 1977), or control (Chandola, Kuper, Singh-Manoux, Bartley, \& Marmot, 2004; Rosenfeld, 1989). Some studies have focused on workload and role burden (Verbrugge, 1987; Baruch \& Barnett, 1986), while a very few have investigated specific measures of domestic role quality (Bartley, Popay \& Plewis, 1992; Schooler, Kohn, Miller \& Miller, 1983). Some investigators hypothesised a process of role trade-off in which emotional and material resources provided by one role were used to meet the demands of another role (Aneshensel, 1986; Thoits, 1987; Waldron, 1980), although Hibbard and Pope (1993) found no interactions between marital quality and work support, each of which were independently protective against mortality among the women in their study. A model which has also focused on interaction effects between roles, but with a specific focus on the stressful aspect of roles, is the spillover model which posits that stressful exposures from home or work sometimes spillover from one environment to another and can eventually lead to role conflict and negative health outcomes (Frone, 1997; Frone, Russell \& Barnes, 1996; Grzywacz \& Marks, 2000; Wortman, Biernat \& Lang, 1991). Similarly, the double exposure (or double burden) model suggests that poor health results if levels of total stress exposure (from stressors unique to home or work or stressors common to both) is high (Hall, 1992; Lundberg, Mardberg \& Frankenhaeuser, 
1994). Stress has often been raised as a potential explanation for relationships between social roles and women's health, although, in a nationally representative sample of Canadian women, McDonough, Walters and Strohschein (2002) found that employed women and mothers had better health than other women despite the fact that they experienced more stress than non-employed and childless women, and concluded that chronic stress was largely irrelevant to the pathways linking social roles and health among women in their sample.

\section{Social roles and a theory of role quality based on agency and structuration} With notable exceptions (for example, Marks 1977; Thoits 1987, 1991), studies of role quality and health have not explicitly drawn on social theory in developing their various concepts of role quality. This paper develops a theory of role quality based on Giddens' theory of structuration and agency in conjunction with Doyal and Gough's theory of human needs, and tests its usefulness in understanding relationships between women's social roles and health using longitudinal data from a British birth cohort study.

\section{Giddens' theory of structuration and agency as quality}

Giddens' theory of structuration (1984) provides a potential model for chracterising social roles in terms of a fusion of structure and agency. This theory advanced an account of the interrelation of structure and agency -- the 'duality of structure' -- in which primacy is granted to neither. Giddens defined 'agency' as both the intentions people have in doing things and their capability of doing those things in the first place. He defined class 'structure' as rules and resources that provide both opportunity and constraint on agency. This theory of structuration might be applied to social roles if, rather than the power associated with class structure to which Giddens refers, we think instead about the power associated with a patriarchal structure that has generated traditional norms 
regarding gender divisions in social roles. Patriarchal power assigns both authoritative and allocative resources to social roles that are traditionally occupied by men, i.e. to paid work rather than domestic roles. Following Gidden's duality of structure and agency as a model, the patriarchal structures associated with gender divisions in social roles provide both opportunity and constraint for agency within these roles. In this way, the quality of a role can be thought of as the extent to which it provides opportunities for autonomous action - for agency.

\section{Linking agency with health: Doyal and Gough's theory of human needs}

The theory of need satisfaction developed by Doyal and Gough (1991) may usefully be combined with that of Giddens for developing theoretical links between role quality and health. Doyal and Gough define 'human need' as that which all humans must achieve if they are to avoid impaired social participation. Doyal and Gough argue that autonomy (which we define as synonymous with agency) and health are the two such basic human needs. Doyal and Gough identify social roles as being a key avenue for providing opportunities or limitations in autonomous social participation: "Having social roles is a universal attribute of human autonomy, notwithstanding the diversity of cultural expectations about how they are defined and allocated" (p.185).

Doyal and Gough's outcome of interest is social participation; however, we theorise a line of association between their restrictions in autonomy needs as a result of role limitations and their other 'basic need', our outcome of interest: health. So, while Doyal and Gough see health and autonomy as the two a-historical, a-cultural needs all humans must satisfy in order to participate in society, we hypothesise that those two needs influence one another, and, specifically, that unsatisfied autonomy needs influence health. Although not explicitly drawn into their model (p. 171), Doyal and Gough also 
highlight the relationship between well-being and restricted opportunities for meeting autonomy needs through role deprivation. The example they use is the influence of unemployment on mental health which was well-documented by the time of Doyal and Gough's publication (Smith, 1987; Warr, 1987) and has since been further documented (Burchell, 1994; Ferrie, Shipley, Marmot, Stansfeld \& Smith, 1998; Morris, Cook \& Shaper, 1994).

\section{Developing and testing a theory of role quality based on agency}

This paper draws together Giddens' theory of structuration in relation to patriarchy rather than class and Doyal and Gough's emphasis on autonomy and health as basic, universal needs in the following way. Social roles are theorized as encompassing the duality of patriarchal structure and agency. Based on Giddens' theory, the rules and resources associated with role structure can be seen as both constricting and enabling opportunities for autonomous agency. (It is worth emphasising again that this paper uses the terms agency and autonomy synonymously. Only the term agency will be used to represent the two throughout the remainder of the paper). Doyal and Gough's conception of agency as a universal need that must be satisfied in order to participate in society is extended and hypothesized as a need which, if chronically unsatisfied, can contribute to poor health outcomes. Therefore, social roles influence health to the extent that their patriarchal structuration restricts opportunities for agency.

This study aims to test this theory of role quality among women from the UK Medical Research Council (MRC) National Study of Health and Development (NSHD), a longitudinal study of 2,547 women and 2,815 men followed-up regularly since their birth in 1946. The vast majority of studies examining relationships between roles and health have been restricted to cross-sectional data sets. Longitudinal data allow us to examine 
whether exposure to particular quality roles over time influences health. The few previous studies to examine relationships between roles and health in prospective data have relied upon social role measures from one (Janzen \& Muhajarine, 2003; Hibbard \& Pope, 1991), or at the most two (Hope, Power, \& Rodgers, 1999a,b) points in the life course, while this study examines the influence of work and family role histories from four points across the adult life course and their relationship with health in mid-life.

Additionally, longitudinal data are necessary for establishing the direction of relationships between roles and health. In previous work we have shown that women in this data set who occupied the multiple roles of mother, wife and employee over the long-term were less likely to report poor health at age 54 than women who lacked one of these main roles, and that this relationship was not explained by health selection (McMunn, Bartley, Hardy \& Kuh, 2006). In this paper we examine whether a theory of role quality based on agency explains this relationship. Of course, patriarchy and class intersect across the life course to structure individuals' life chances. For example, class is strongly associated with women's labour force participation (Joshi \& Hinde, 1993; Joshi \& Paci, 1998) as well as partnership and parenthood patterns (Kiernan \& Diamond, 1983; Kiernan \& Eldridge, 1987), and these relationships vary by cohort (Ferri \& Smith, 2003; Joshi, 1996; Joshi \& Hinde, 1993; Macran, Joshi, \& Dex, 1996). This study is also able to control for the influence of life time socioeconomic circumstances on relationships between role histories and health in mid-life among women in this birth cohort.

Figure 1 presents a longitudinal model of social roles, socioeconomic circumstances and health across the life course. This model provides an analytical framework for examination of relationships between role histories, role quality and health in mid-life, also taking into account the potential influence of socioeconomic circumstances. 
Figure 1 about here.

\section{METHODS}

The UK MRC NSHD (otherwise known as the 1946 birth cohort) originated as a study of 2,547 women and 2,815 men who were born in the first week of March in 1946 (Wadsworth, 1991; Joint Committee of the Royal College of Obstetricians and Gynaecologists and the Population Investigation Committee, 1948).

\section{Measures}

\section{Health in mid-life}

Self-reported health at age 54 was collected as part of a series of postal questionnaires that were sent to women in the cohort every year between ages 47 and 54 . Of the original cohort of women, $6 \%$ had died, $9 \%$ were living abroad and were not in contact with the study, $12 \%$ had refused to take part at earlier follow-ups, $3 \%$ could not be traced, and $19 \%$ became non-responders over the course of the eight women's health surveys, resulting in 1,294 women with a measure of self-reported health at age 54 . Response categories for self-reported health were 'excellent', 'good', 'fair' and 'poor'. For analysis, women who reported fair or poor health were considered to have poor subjective health (nearly a third).

\section{Social role histories}

In adulthood, information has been collected in face-to-face interviews at ages 26, 36, 43 and 53, with postal follow-ups between some waves (Wadsworth, Butterworth, Hardy, Kuh, Richards, Langenberg, et al., 2003). Information about women's work status 
collected at these ages was combined with marital and parental status information collected at age 53 to create a social role history variable with six categories. Of the 1,294 women with a measure of self-reported health, $1,171(90.5 \%)$ had social role history information available. Women who held all three of the main social roles of employee, spouse and mother over the long-term were designated as the reference category. Women in this Multiple roles group $(n=453)$ were married to one husband (the NSHD has not collected full histories of non-marital partnerships to date), had children and had relatively strong long-term ties to the labour market (employed at three or four of the four ages of data collection). Three categories of role histories were defined by the long-term absence of one of the main roles of employee, spouse or mother. Childless $(n=141)$ women did not have children. Homemakers $(n=117)$ were full-time homemakers at three or four of the four ages of data collection. Lone mothers (n $=184$ ) were either never married (only 7 women) or previously married mothers (mostly the latter). Finally, there were two categories of role histories that were not defined by the absence of a main role, but made up substantial groups in their own right. These were Remarried mothers $(\mathrm{n}=151)$ and Intermittent employed married mothers $(\mathrm{n}=125)$ who were married to one husband and had children, but whose labour market ties were weaker than those of Multiple roles women and stronger than those of Homemakers. In comparison with the 1991 Census, full-time employed women and widowed women were over-represented, while never married, separated and divorced women were under-represented, at ages 43 and 53 of the study (Wadsworth et al. 2003).

\section{Agency}

The concept of agency as a possible mediator of the relationship between role histories and the subjective health of women in this cohort in mid-life was operationalised in two 
ways: quality of paid or unpaid work at age 36 and family and work stress between ages 48 and 54.

Work quality (paid and unpaid) at age 36

At age 36, a set of questions was asked about respondents' main role. If women were employed outside the home at age 36 , they were asked about their paid work. If women were keeping house full-time, they were asked identical questions about looking after the home. These questions centred around three aspects of women's main work role which can be thought of as indicators of agency or opportunities for agency: whether women enjoyed this role, how demanding they found it to be, both physically and emotionally, and whether they had any skills or talents that were going unused in their main work role. Response categories for each of these variables were assigned a score of 0 to 2 ( 0 as most positive and 2 as most negative) and combined to create a five-point work role quality scale in which $8 \%$ of women were in an excellent quality main work role, $21 \%$ in a good quality main work role, $42 \%$ were in a fair quality work role, $18 \%$ in a poor quality work role and $11 \%$ were in a very poor quality work role.

Family and work stress, ages 48-54

A second set of variables identified as potentially inhibiting opportunities for agency within work and family roles was family and work related stress, collected between ages 48 and 54 . The measure of family and work stress was based on several sets of questions about women's work and family lives that were included in a women's health questionnaire posted to female members of the cohort every year between ages 48 and 54. These included identical questions about whether women's work or family lives had improved or got worse over the past year, another set of questions which asked about any serious difficulties in respondents' work or family lives over the last year, and open- 
ended questions about whether anything in respondents' lives had improved or worsened in the past year. If women gave details of events related to work or family in these open-ended questions, these were included in the measure of work and family stress. These were combined to create measures of family and work stress for each year. These single-year stress scores were added together to create a cumulative family and work stress score between ages 48 and 54 with a range of 0-50 (median $=9$ ). The continuous family and work stress score was categorised into quintiles for analysis here.

\section{Life time socioeconomic circumstances}

Childhood social class was measured using the Registrar General's social class of their father's occupation when cohort women were 11 years old categorised into four groups: classes I and II combined, III Non-Manual, III Manual, and classes IV and V combined. If father's occupation at age 11 was unknown, similar measures at 16 or 4 years were used. Education, measured using the level of the highest educational or training attainment by 26 years as classified by the Burnham scale (DES, 1972), was categorised into: degree level, 'A' level or equivalent, 'O' level or equivalent, vocational or sub ' $\mathrm{O}$ ' level qualifications, and those with no qualification. Adult socioeconomic circumstances were measured using Registrar General's social class based both on the occupation of the head of household and women's own occupation at age 43 , as this was the age of data collection in which households tended to reach their highest class level. The categories used were identical to those used for childhood social class.

\section{Analytical techniques}

First, univariate relationships between role histories and self-reported health at age 54, and then between indicators of role quality, socio-economic circumstances and role histories are shown using proportions. Next, a series of multivariable logistic regression 
models tested the influence of role quality and socioeconomic indicators on relationships between role histories and reporting poor health at age 54 to determine whether role quality indicators mediated relationships between role histories and health in mid-life, and whether relationships between roles and health, or the influence of role quality measures on relationships between roles and health, were confounded by socioeconomic circumstances.

\section{RESULTS}

Table 1 shows the relationship between role histories and health in mid-life that we set out to explain by indicators of agency as role quality. Women in each of the groups lacking one of the main roles of employee, spouse or mother (i.e. Homemakers, Lone mothers, and Childless women) were significantly more likely to report poor health at age 54 than women in the Multiple roles group. Table 1 also shows the strikingly low proportion (3\%) of Homemakers who reported having excellent health.

\section{Table 1 about here}

Does role quality mediate the relatively good reported health at age 54 of women in multiple roles?

\section{Work quality (paid and unpaid) at age 36}

Table 2 shows that work quality at age 36 was related to role histories. Women with Multiple role histories were least likely to report poor work quality at age 36 , and Intermittent employed married mothers were most likely. 


\section{Table 2 about here}

Table 3 (Column 1) shows that work quality was associated with increasing odds of reporting fair or poor health at age 54 . The inclusion of the quality of women's main work role at age 36 and role histories in a multivariable model slightly attenuated the odds of reporting poor health at 54 for the two groups of women with the weakest ties to the labour market -- Homemakers and Intermittent employed married mothers -- compared with the Multiple roles group (Table 3, Column 2).

\section{Table 3 about here}

\section{Family and work stress, ages 48-54}

Table 2 shows that family and work stress between ages 48 and 54 was not significantly associated with role histories in bi-variate analysis. In Table 3 (Column 1), the odds of reporting poor health increased with each increasing quintile of work and family stress. In the multivariable model including role histories and family and work stress, stress was an important mediator of the effect of lone motherhood on health (Table 3, Column 3). The odds of reporting poor health among Lone mothers compared with the Multiple roles group declined from $1.59(1.10-2.29)$ to $1.29(0.88-1.90)$ (Table 3).

\section{Do socioeconomic circumstances explain the relatively good reported health at age 54 of women in multiple roles?}

Table 2 shows that Childless women (the group with the strongest ties to the labour market) were the most likely group to have been raised in a professional or managerial household, to have educational qualifications, to live in a non-manual household, and to be in a professional or managerial occupation themselves. We might expect 
socioeconomic circumstances to explain the poor subjective health of Homemakers and Lone mothers in particular as Table 2 shows that Homemakers were the least likely to have any educational qualifications and that both Homemakers and Lone mothers were the most likely groups to live in a routine or semi-routine occupational household.

Table 2 shows that neither childhood social class nor women's own social class was associated with role histories. Women's own social class was associated with reporting fair or poor health at age 54 (not shown), but neither childhood social class nor education were ( $p=0.1$ and $p=0.5$, respectively) and none of these three measures influenced relationships between role histories and self-reported health (not shown). Despite significant relationships between social class of head of household and both role histories (Table 2) and self reported health at age 54 (Table 3, Column 1), relationships between role histories and reported poor health at 54 persisted after adjusting for adult social class. However, the odds of reporting poor health among Lone mothers was reduced slightly when social class was introduced into the model (Table 3, Column 4).

The final model including work quality, family and work stress and social class of head of household explained the poor reported health in mid-life of Lone mothers (Table 3, Column 5). The odds of reporting poor health among long-term Homemakers was reduced a little, but remained strong and significant (Table 3, Column 5) while the relatively high odds of reporting poor health among Childless women was unchanged by the inclusion of work quality, family and work stress and social class (Table 3, Column 5). Both family and work stress, and social class of head of household remained significantly associated with self reported health at age 54 in the final model. 


\section{DISCUSSION}

This paper developed a theory of role quality in which the patriarchal structuration (drawing on Giddens' term) of work and family roles provides both limitation and opportunity for expression of agency. Further, Doyal \& Gough's theory of human needs was used to identify the restriction of agency as a possible influence on health. This theory of role quality was hypothesised as potentially explaining the poor reported health in mid-life of long-term homemakers, lone mothers and childless women in comparison with women who had occupied all three roles of mother, wife and paid worker over the long-term among women in the 1946 birth cohort. The hypothesis was that the restriction of homemakers, lone mothers and childless women to one or two of the three roles of mother, wife or paid worker represents a relative limitation in resources or opportunities for agency, in comparison with women who occupied all three roles, ultimately leading to relatively worse subjective health in mid-life. This study operationalised agency, and factors that could inhibit agency, in relation to work and family roles at various ages across adulthood using existing data in this cohort, namely quality of main work role at age 36 and family and work stress between ages 48 and 54 . Quality of main work role at age 36 , family and work stress between ages 48 and 54 , and social class varied in their importance for lone mothers, homemakers and childless women.

The poor health of lone mothers at age 54 was largely explained in terms of a combination of family and work stress and social class. A picture emerges in which heavy restrictions in role-related opportunities for agency result from the material and non-material stresses associated with lone parenting. The influence of adult social class was expected considering the relative disadvantage of lone mothers in this cohort in terms of education and class position as well as the high prevalence of poverty in lone parent families compared with two parent families more generally (Allan, 1999; Arendell, 
1987; Devillier \& Forsyth, 1988; Duncan \& Hoffman, 1985; Everett, 1991; Jarvis \& Jenkins, 1998; Maclean, 1991; Shouls, Whitehead, Burstrom \& Diderichsen, 1999). Additional measures of socioeconomic circumstances may have reduced the high odds of reporting poor health among lone mothers further. Arber and Cooper (2000) have shown that much, but not all, of the poor reported health of lone mothers was explained by material circumstances in cross-section. The mediating effect of stress on the health of lone mothers was stronger in this study than in a recent cross-sectional Canadian study which found that chronic stress reduced, but did not eliminate, the greater likelihood of mental distress among divorced women compared with married women (McDonough, Walters, et al., 2002).

In contrast, the poor health in mid-life of long-term homemakers and childless women was less easily accounted for. The quality of women's main work role at age 36 explained a small amount of the odds of reporting poor health among long-term homemakers, but their excess risk of reporting poor health remained strong and significant. None of the factors considered influenced the poor reported health at age 54 of childless women. Indeed, childless women were at increased risk for reporting poor health despite their high levels of educational attainment and the social advantage inherent in occupying professional or managerial occupational class positions.

The use of a subjective measure of health may mean that the relationships shown here represent relationships between roles and mental health, as there is likely to be at least an element of mental health within the subjective health measure (Blaxter, 1990). Nearly all previous studies of roles and health have focused on mental or subjective health or mortality (see Hibbard \& Pope, 1991, 1993; McMunn et al., 2006 for exceptions). Relationships between roles and health may vary depending on the measure of health 
used; for example, we have shown this to be the case for obesity (McMunn et al., in press). However, the poor subjective health of childless women shown here has also been found in relation to mortality. For example, Grundy and Tomassini (2005) found that nulliparous women in the $1 \%$ sample of the ONS Longitudinal Study born between 1911 and 1940 were significantly more likely than their parous counterparts to have died by 1991 . The relatively poor health in mid-life of childless women may reflect biological pathways, either pre-existing health problems that made motherhood less likely or specific diseases associated with childlessness such as breast cancer. In addition, being childless may influence the health of women in mid-life via psychosocial pathways, for instance, through a lack of social support from children or feelings that the opportunity to have children was somehow denied, in other words, a restriction of agency.

This study has provided longitudinal support for the role enhancement hypothesis, and has provided evidence that it is not explained by markers of socioeconomic circumstances. The hypothesis that relationships between social roles and health might be explained by a theory of role quality defined by the opportunities and restrictions that roles provide for agency was only supported for long-term lone mothers, and not for long-term homemakers or childless women. This may mean that a theory of role quality based on opportunities for autonomous action is not widely applicable, and that an alternative theory of role quality is needed. On the other hand, the measures of role quality available in the 1946 cohort, and only at certain ages, may not have adequately captured the concept of lifetime role-related agency. For example, the measure of work quality at age 36 used here is likely to underestimate the opportunity for women in multiple roles to meet agency in roles outside paid employment. This study highlights the need to develop measures of role quality specifically designed to capture agency aspects of social roles. 


\section{REFERENCES}

Allan, G. (Ed.) (1999). The sociology of the family. Oxford: Blackwell.

Aneshensel, C. (1986). Marital and employment role-strain, social support and depression among adult women. In: S. Hobfoll (Ed.), Stress, Social support and Women. Washington DC: Hemisphere.

Arber, S. \& Cooper, H. (2000) Gender inequalities in health across the lifecourse. In: E. Annandale \& K. Hunt (Eds.), Gender Inequalities in Health. Buckingham: Open University Press.

Arendell, T.J. (1987). Women and the economics of divorce in the contemporary United States. Signs, 13, 473-497.

Barnett, R., \& Hyde, J. (2001). Women, men, work and family. An expansionist theory, American Psychologist, 56, 781-796.

Bartley, M., Popay, J., \& Plewis, I. (1992). Domestic conditions, paid employment and women's experience of ill health. Sociology of Health \& IIIness, 14, 313-343.

Baruch, G.K., \& Barnett, R. (1986). Role quality, multiple role involvement, and psychological well-being in mid life women. Journal of Personality and Social Psychology, 51, 578-585.

Blaxter, M. (1990). Health and Lifestyles. London: Routledge.

Burchell, B. (1994). The effects of labour market position, job insecurity and unemployment on psychological health. In: D. Gallie, C. Marsh, C. Vogler (Eds.), Social Change and the Experience of Unemployment. Oxford: Oxford University Press.

Chandola, T., Kuper, H., Singh-Manoux, A., Bartley, M., \& Marmot, M. (2004). The effect of control at home on CHD events in the Whitehall II study: Gender differences in psychosocial domestic pathways to social inequalities in CHD. Social Science \& Medicine, 58, 1501-1509.

Crosby, F.J. (1987). Spouse, parent, worker: On gender and multiple roles. New Haven, CT: Yale University Press.

Department of Education and Science. (1972). Burnham Further Education Committee Grading Courses 1972. London: HMSO.

Devellier, P.L., \& Forsyth, C.J. (1988). The downward mobility of divorced women with dependent children: A research note. Sociological Spectrum, 8, 295-302.

Doyal, L., \& Gough, I. (1991). A Theory of Human Need. London: The Macmillan Press Ltd.

Duncan, G.J., \& Hoffman, S.D. (1985). A reconsideration of the economic consequences of marital dissolution. Demography, 22, 485-497. 
Everett, C.A. (Ed.) (1991). The consequences of divorce: Economic and custodial impact on children and adults. New York: Haworth Press.

Feld, S. (1963). Feelings of adjustment. In: FI. Nye \& LW Hoffman (Eds.), The Employed Mother in America. Chicago: Rand McNally.

Ferri, E., \& Smith, K. (2003). Chapter 4 Partnerships and parenthood. In: E. Ferri, J. Bynner \& M. Wadsworth (Eds.), Changing Britain, Changing Lives: Three Generations at the Turn of the Century. London: Institute of Education, University of London.

Ferrie, J.E., Shipley, M.J., Marmot, M.G., Stansfeld, S.A., \& Smith, G.D. (1998). An Uncertain Future: The Health Effects of Threats to Employment Security in White-Collar Men and Women. American Journal of Public Health, 88, 1030-1036.

Frone, M.R. (1997). Relation of work-family conflict to health outcomes: A four-year longitudinal study of employed parents. Journal of Occupational and Organizational Psychology, 70, 325-335.

Frone, M.R., Russell, M., \& Barnes, G.M. (1996). Work-family conflict, gender, and health-related outcomes: A study of employed parents in two community samples. Journal of Occupational Health Psychology, 1, 57-69.

Giddens, A. (1984). The Constitution of Society: Outline of the Theory of Structuration. Berkeley: University of California Press.

Goode, W.J. (1960). A theory of role strain. American Sociological Review, 25, 483-496.

Grundy, E., \& Tomassini, C. (2005). Fertility history and health in later life: a record linkage study in England and Wales. Social Science and Medicine, 61, 217-228.

Grzywacz, J.G., \& Marks, N.F. (2000). Reconceptualizing the work-family interface: An ecological perspective on the correlates of positive and negative spillover between work and family. Journal of Occupational Health Psychology, 5, 111-126.

Hall, E.M. (1992). Double exposure: The combined impact of the home and work environments on psychosomatic strain in Swedish women and men. International Journal of Health Services, 22, 239-260.

Hibbard, J.H., \& Pope, C.R. (1993). The quality of social roles as predictors of morbidity and mortality, Social Science \& Medicine. 36, 217-225.

Hibbard, J., \& Pope, C. (1991). Effects of domestic and occupational roles on morbidity and mortality. Social Science \& Medicine, 32, 805.

Hope, S., Power, C., \& Rodgers, B. (1999a). Does financial hardship account for elevated psychological distress in lone mothers? Social Science \& Medicine, 49, 16371649. 
Hope, S., Power, C., \& Rodgers, B. (1999b) Marital status transitions and psychological distress: longitudinal evidence from a national population sample. Psychological Medicine, 29, 381-389.

Janzen, B.L., Muhajarine, N. (2003) Social role occupancy, gender, income adequacy, life stage and health: a longitudinal study of employed Canadian men and women. Social Science and Medicine, 57, 1491-1503.

Jarvis, S., \& Jenkins, S.P. (1998) Marital dissolution and income change: Evidence for Britain. In: R. Ford \& J. Millar (Eds.), Private lives \& public responses. London: Policy Studies Institute.

Joint Committee of the Royal College of Obstetricians and Gynaecologists and the Population Investigation Committee. (1948). Maternity in Great Britain. Oxford: Oxford University Press.

Joshi, H. (1996). ‘Combining Employment and Child-rearing: the story of British women's lives'. In A. Offer (Ed.), In Pursuit of Quality of Life.

Joshi, H., \& Hinde, P.R.A. (1993). Employment after Child-Bearing in Post-War Britain: Cohort Study Evidence on Contrasts within and across Generations. European Sociological Review, 9, 203-227.

Joshi, H., \& Paci, P. (1998). Unequal Pay for Women and Men: evidence from the British birth cohort studies. Cambridge, MA: MIT Press.

Kiernan, K.E., \& Diamond, I. (1983). The Age at Which Childbearing Starts - a Longitudinal Study. Population Studies, 37, 3663-380.

Kiernan, K.E., \& Eldridge, S.M. (1987). Age at marriage: inter and intra cohort variation. The British Journal of Sociology, 38, 44-65.

Lundberg, U., Mardberg, B., \& Frankenhaeuser, M. (1994). The total workload of male and female white collar workers as related to age, occupational level, and number of children. Scandinavian Journal of Psychology, 35, 315-327.

Maclean, M. (1991). Surviving divorce: Women's resources after separation. London: Macmillan.

Macran, S., Clarke, L., Sloggett, A., \& Bethune, A. (1994). Women's socio-economic status and self-assessed health: identifying some disadvantaged groups. Sociology of Health \& Illness, 16, 182-208.

Macran, S., Joshi, H., \& Dex, S. (1996). Employment after Childbearing: A Survival Analysis. Work, Employment and Society, 10, 273-296.

Marks, S.R. (1977). Multiple roles and role strain: some notes on human energy, time and commitment. American Sociological Review, 42, 921-936.

McDonough, P., Walters, V., \& Strohschein, L. (2002). Chronic stress and the social patterning of women's health in Canada. Social Science \& Medicine, 54, 767-782. 
McMunn, A., Bartley, M., Hardy, R., \& Kuh, D. (2006) Life course social roles and women's health in mid-life: causation or selection? Journal of Epidemiology \& Community Health, 60(6), 484-489.

Moen, P., Dempster-McClain, D., \& Williams, R.M. Jr. (1989). Social integration and longevity: An event history analysis of women's roles and resilience. American Sociological Review, 54, 635-647.

Morris, J.K., Cook, D.G., \& Shaper, A.G. (1994). Loss of employment and mortality. British Medical Journal, 308, 1135-1139.

Repetti, R.L. (1998). Multiple Roles (Chapter 27). In: E.A. Blechman \& K.D. Brownell (Eds.), Behavioral Medicine and Women: a comprehensive handbook. New York: The Guildford Press.

Repetti, R.L., Matthews, K., \& Waldron, I. (1989) Employment and women's health. American Psychologist, 44, 1394-1401.

Rosenfeld, S. (1989). The effects of women's employment, personal control and sex differences in mental health. Journal of Health and Social Behaviour, 30, 77-91.

Schooler, C., Kohn, M.L., Miller, K.A., \& Miller. J. (1983). Housework as work. In C.A. Schooler \& M.L. Kohn (Eds.), Work and personality: An inquiry into the impact of social stratification. Norwood, NJ: Ablex Publishing Co.

Shouls, S., Whitehead, M., Burstrom, B., \& Diderichsen, F. (1999). The health and socioeconomic circumstances of British lone mothers over the last two decades. Population Trends, 95, 41-46.

Sieber, S.A. (1974). Towards a theory of role accumulation. American Sociological Review, 39, 567-578.

Smith, R. (1987). Unemployment and Health. Oxford: Oxford University Press.

Thoits, P.A. (1991) On Merging Identity Theory and Stress Research. Social Psychology Quarterly, 54, 101-112.

Thoits, P. (1987). Negotiating roles. In FJ Crosby (Ed.), Spouse, Parent, Worker, On Gender and Multiple Roles. London: Yale UP.

Thoits, P. (1986). Multiple identities: examining gender and marital status differences in distress. American Sociological Review, 51, 259-272.

Verbrugge, L.M. (1987), Role responsibilities, role burdens and physical health. In: F.J. Crosby (Ed.), Spouse, Parent, Worker. London: Yale University Press.

Verbrugge, L. (1983). Multiple roles and physical health of women and men. Journal of Health and Social Behaviour, 24, 16-30. 
Wadsworth, M.E.J., Butterworth, S.L., Hardy, R.J., Kuh, D.J., Richards, M., Langenberg, C., Hilder, W.S., \& Connor, M. (2003). The life course prospective design: an example of benefits and problems associated with study longevity. Social Science \& Medicine, 57, 2193-2205.

Wadsworth, M.E.J. (1991). The Imprint of Time: Childhood, history and adult life. Oxford: Oxford University Press.

Waldron, I. (1980). Employment and women's health: An analysis of causal relationships. International Journal of Health Services, 10, 435-454.

Waldron, I., Weiss, C.C., \& Hughes, (1998). Interacting effects of multiple roles on women's health. Journal of Health and Social Behavior, 39, 216-236.

Warr, P. (1987). Work, Unemployment and Mental Health. Oxford: Clarendon Press.

Wortman, C., Biernat, M., \& Lang, E. (1991). Coping with role overload. In M.

Frankenhaeuser, U. Lundberg \& M. Chesney (Eds.), Women, work and health: stress and opportunities (pp. 85-110). New York: Plenum Press. 


\section{Tables and figures}

Figure 1 Longitudinal model for studying adult social roles and subjective health in later life.*

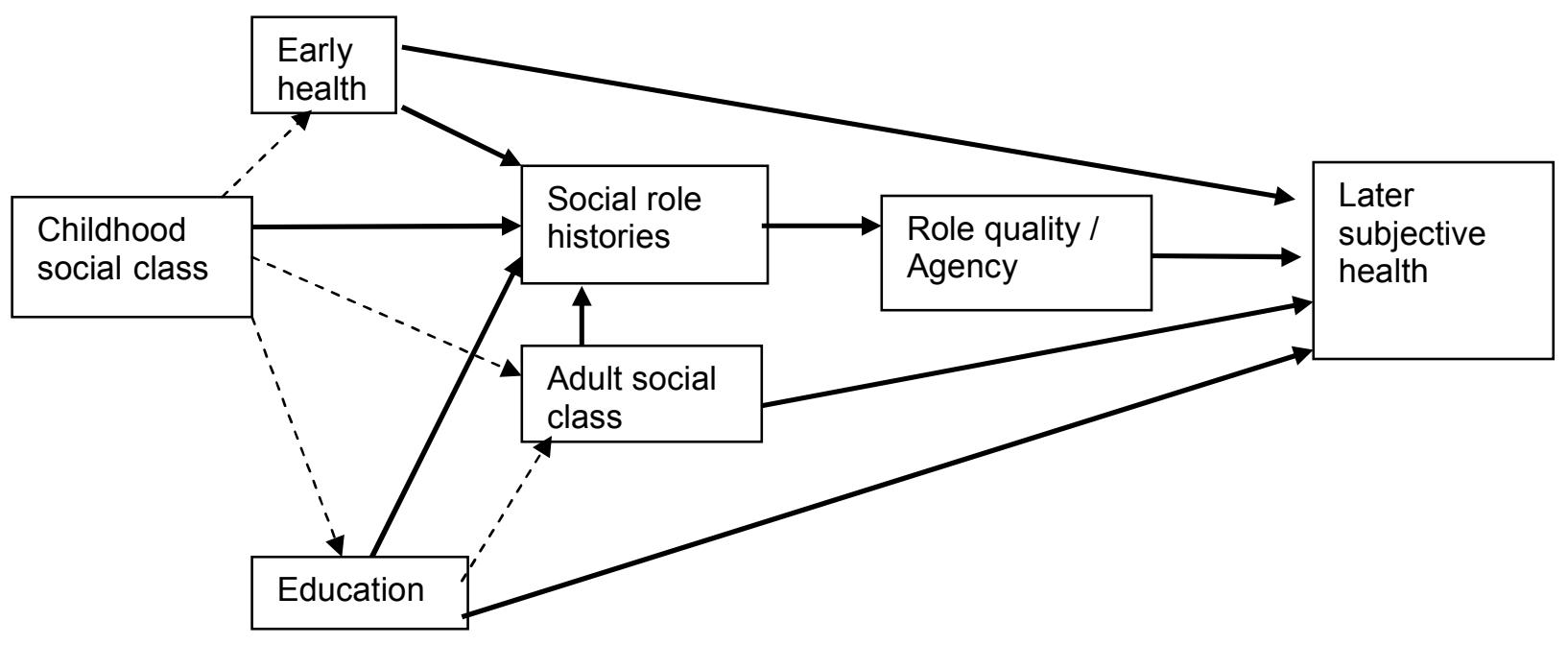

TIME

* The pathways in Figure 1 delineated by broken lines are not examined in this paper. 
Table 1 Self-reported health at age 54 by role histories among women in the NSHD 1946 birth cohort.

\begin{tabular}{|l|c|c|c|c|c|c|c|}
\hline $\begin{array}{c}\text { SELF-REPORTED } \\
\text { HEALTH }\end{array}$ & $\mathbf{N}$ & $\begin{array}{c}\text { Multiple } \\
\text { roles } \\
\%\end{array}$ & $\begin{array}{c}\text { Homemakers } \\
\%\end{array}$ & $\begin{array}{c}\text { Lone } \\
\text { mothers } \\
\%\end{array}$ & $\begin{array}{c}\text { Childless } \\
\%\end{array}$ & $\begin{array}{c}\text { Remarried } \\
\text { mothers } \\
\%\end{array}$ & $\begin{array}{c}\text { Intermittent employed } \\
\text { married mothers } \\
\%\end{array}$ \\
\hline Excellent & 125 & 13.0 & 2.6 & 11.4 & 11.3 & 7.9 & 11.2 \\
Good & 665 & 60.5 & 55.6 & 52.2 & 52.5 & 58.9 & 53.6 \\
Fair & 322 & 23.0 & 33.3 & 32.1 & 28.4 & 27.2 & 31.2 \\
Poor & 59 & 3.5 & 8.5 & 4.3 & 7.8 & 6.0 & 4.0 \\
Total & $\mathbf{1 1 7 1}$ & $\mathbf{1 0 0}$ & $\mathbf{1 0 0}$ & $\mathbf{1 0 0}$ & $\mathbf{1 0 0}$ & $\mathbf{1 0 0}$ & $\mathbf{1 0 0}$ \\
\hline
\end{tabular}

Overall: $\chi^{2}=28.05, p=0.02$ 
Table 2 Social role histories by indicators of role quality and lifetime socioeconomic circumstances among women in the NSHD 1946 birth cohort.

\begin{tabular}{|c|c|c|c|c|c|c|c|c|}
\hline $\begin{array}{l}\text { ROLE QUALITY } \\
\text { INDICATORS }\end{array}$ & $\mathbf{N}$ & $\begin{array}{l}\text { Multiple } \\
\text { roles }\end{array}$ & Homemakers & $\begin{array}{l}\text { Lone } \\
\text { mothers }\end{array}$ & Childless & $\begin{array}{l}\text { Remarried } \\
\text { mothers }\end{array}$ & $\begin{array}{l}\text { Intermittent employed } \\
\text { married mothers }\end{array}$ & Total \\
\hline $\begin{array}{l}\text { Work quality (paid } \\
\text { and unpaid) age } 36\end{array}$ & & $\%$ & $\%$ & $\%$ & $\%$ & $\%$ & $\%$ & $\%$ \\
\hline $\begin{array}{l}\text { Excellent } \\
\text { Good } \\
\text { Fair } \\
\text { Poor } \\
\text { Very poor } \\
\text { Missing } \\
\text { Total } \\
\chi^{2}=53.08, \mathrm{p}<0.001^{*}\end{array}$ & $\begin{array}{c}86 \\
220 \\
435 \\
182 \\
114 \\
134 \\
1171\end{array}$ & $\begin{array}{c}9.3 \\
21.4 \\
38.0 \\
14.6 \\
7.1 \\
9.7 \\
100\end{array}$ & $\begin{array}{c}2.6 \\
9.4 \\
45.3 \\
17.1 \\
12.8 \\
12.8 \\
100\end{array}$ & $\begin{array}{c}8.2 \\
17.4 \\
37.5 \\
12.5 \\
9.2 \\
15.2 \\
100\end{array}$ & $\begin{array}{c}5.7 \\
23.4 \\
40.4 \\
14.2 \\
7.8 \\
8.5 \\
100\end{array}$ & $\begin{array}{c}7.9 \\
23.2 \\
27.2 \\
17.9 \\
9.3 \\
14.6 \\
100\end{array}$ & $\begin{array}{c}4.8 \\
9.6 \\
34.4 \\
20.8 \\
20.0 \\
10.4 \\
100\end{array}$ & $\begin{array}{c}7.3 \\
18.8 \\
37.1 \\
15.5 \\
9.7 \\
11.4 \\
100\end{array}$ \\
\hline $\begin{array}{l}\text { Family and work } \\
\text { stress, ages } 48-54\end{array}$ & & $\%$ & $\%$ & $\%$ & $\%$ & $\%$ & $\%$ & $\%$ \\
\hline $\begin{array}{l}\text { Lowest quintile } \\
2^{\text {nd }} \text { quintile } \\
3^{\text {rd }} \text { quintile } \\
4^{\text {th }} \text { quintile } \\
\text { Highest quintile } \\
\text { Missing } \\
\text { Total } \\
\chi^{2}=27.69, p=0.1^{*}\end{array}$ & $\begin{array}{c}181 \\
199 \\
171 \\
170 \\
199 \\
251 \\
1171\end{array}$ & $\begin{array}{c}18.1 \\
17.0 \\
17.2 \\
13.2 \\
14.1 \\
20.3 \\
100\end{array}$ & $\begin{array}{l}17.1 \\
17.1 \\
12.8 \\
17.1 \\
15.4 \\
20.5 \\
100\end{array}$ & $\begin{array}{c}9.2 \\
14.1 \\
11.4 \\
14.7 \\
25.5 \\
25.6 \\
100\end{array}$ & $\begin{array}{l}11.3 \\
19.9 \\
13.5 \\
16.3 \\
17.7 \\
21.3 \\
100\end{array}$ & $\begin{array}{l}15.9 \\
15.9 \\
14.6 \\
11.9 \\
16.6 \\
25.2 \\
100\end{array}$ & $\begin{array}{c}17.6 \\
19.2 \\
12.8 \\
17.6 \\
16.0 \\
16.8 \\
100\end{array}$ & $\begin{array}{l}15.5 \\
17.0 \\
14.6 \\
14.5 \\
17.0 \\
21.4 \\
100\end{array}$ \\
\hline \multicolumn{9}{|l|}{$\begin{array}{l}\text { LIFETIME } \\
\text { SOCIOECONOMIC } \\
\text { CIRCUMSTANCES }\end{array}$} \\
\hline Childhood social class & & $\%$ & $\%$ & $\%$ & $\%$ & $\%$ & $\%$ & $\%$ \\
\hline $\begin{array}{l}\text { I/II } \\
\text { IIINM } \\
\text { IIIM } \\
\text { IV/V } \\
\text { Missing }\end{array}$ & $\begin{array}{c}311 \\
189 \\
345 \\
268 \\
58\end{array}$ & $\begin{array}{c}27.8 \\
16.6 \\
27.6 \\
23.6 \\
4.4\end{array}$ & $\begin{array}{c}21.4 \\
17.9 \\
29.1 \\
25.6 \\
6.0\end{array}$ & $\begin{array}{c}21.2 \\
17.4 \\
34.8 \\
21.7 \\
4.9\end{array}$ & $\begin{array}{c}34.0 \\
12.8 \\
27.0 \\
19.9 \\
6.4\end{array}$ & $\begin{array}{c}26.5 \\
12.6 \\
33.1 \\
22.5 \\
5.3\end{array}$ & $\begin{array}{c}26.4 \\
19.2 \\
27.2 \\
23.2 \\
4.0\end{array}$ & $\begin{array}{c}26.6 \\
16.1 \\
29.5 \\
22.9 \\
5.0\end{array}$ \\
\hline
\end{tabular}




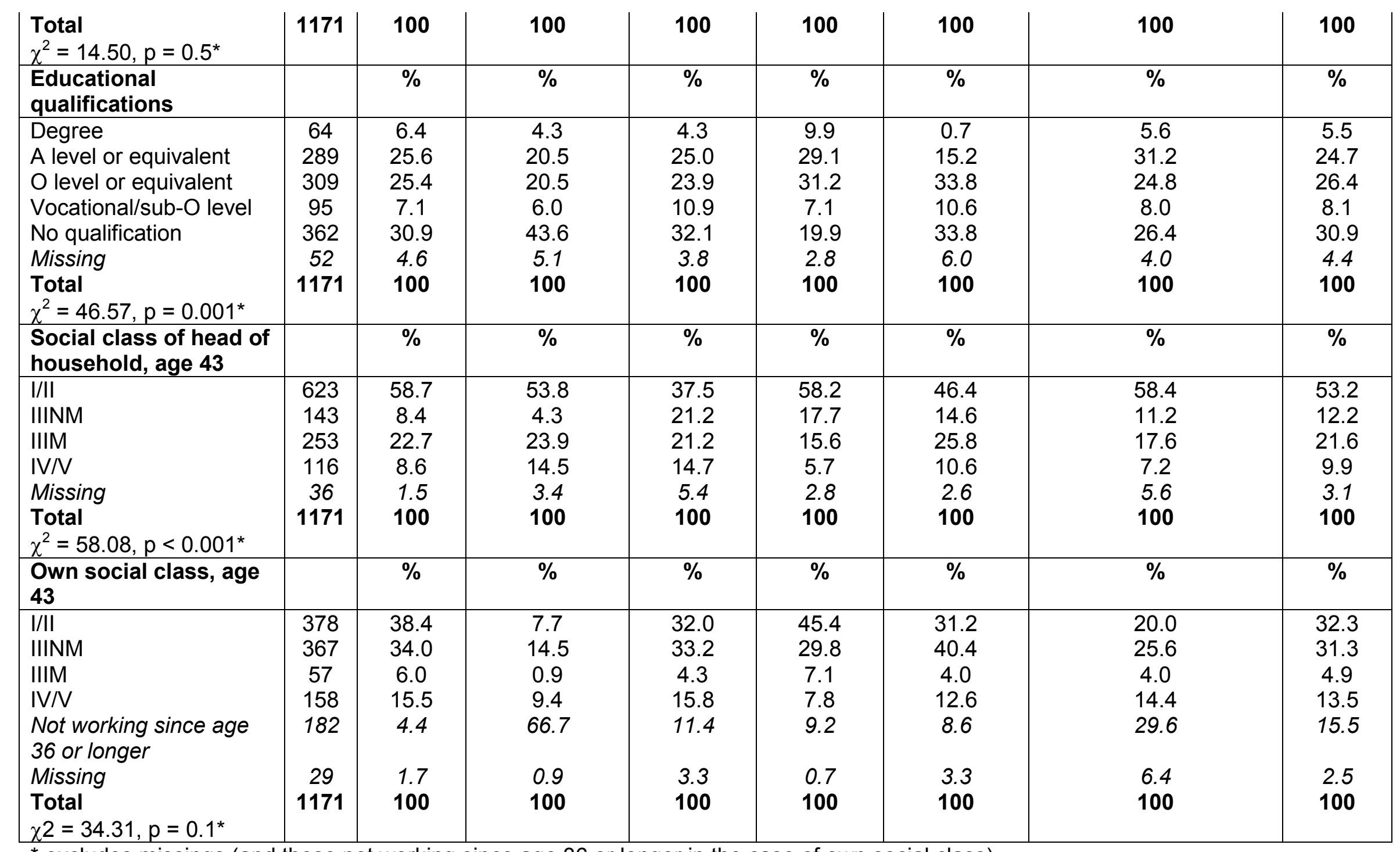

${ }^{*}$ excludes missings (and those not working since age 36 or longer in the case of own social class). 
Table 3 Odds ratios $(95 \% \mathrm{Cl})$ of reporting poor health at age 54 by role histories, role quality and adult social class among women in the NSHD 1946 birth cohort, unadjusted and four multivariable models.

\begin{tabular}{|c|c|c|c|c|c|c|c|c|c|c|c|}
\hline \multirow[b]{2}{*}{ Role histories } & \multirow[b]{2}{*}{$\mathrm{N}=1171$} & \multicolumn{2}{|c|}{$\begin{array}{l}\text { Separate } \\
\text { unadjusted } \\
\text { models } \\
\text { Column } 1\end{array}$} & \multicolumn{2}{|c|}{$\begin{array}{l}\text { Multivariable } \\
\text { model, adjusted } \\
\text { for work quality } \\
\text { at age } 36 \\
\text { Column } 2\end{array}$} & \multicolumn{2}{|c|}{$\begin{array}{l}\text { Multivariable } \\
\text { model, adjusted } \\
\text { for work \& family } \\
\text { stress, ages 48- } \\
54 \\
\text { Column } 3\end{array}$} & \multicolumn{2}{|c|}{$\begin{array}{l}\text { Multivariable } \\
\text { model, adjusted } \\
\text { for social class } \\
\text { of head of } \\
\text { household, at } \\
\text { age } 43 \\
\text { Column } 4 \\
\end{array}$} & \multicolumn{2}{|c|}{$\begin{array}{l}\text { Multivariable } \\
\text { model, adjusted for } \\
\text { all three } \\
\text { Column } 5\end{array}$} \\
\hline & & OR & $95 \% \mathrm{Cl}$ & OR & $95 \% \mathrm{Cl}$ & OR & $95 \% \mathrm{Cl}$ & OR & $95 \% \mathrm{Cl}$ & OR & $95 \% \mathrm{Cl}$ \\
\hline Multiple roles & 453 & 1.00 & & 1.00 & & 1.00 & & 1.00 & & 1.00 & \\
\hline Homemakers & 117 & 2.00 & $1.31-3.05$ & 1.85 & $1.20-2.84$ & 2.09 & $1.34-3.26$ & 1.91 & $1.25-2.94$ & 1.88 & $1.19-2.97$ \\
\hline Lone mothers & 184 & 1.59 & $1.10-2.29$ & 1.58 & $1.09-2.27$ & 1.29 & $0.88-1.90$ & 1.46 & $1.00-2.13$ & 1.18 & $0.79-1.75$ \\
\hline Childless & 141 & 1.57 & $1.05-2.35$ & 1.56 & $1.04-2.33$ & 1.50 & $0.98-2.28$ & 1.64 & $1.09-2.47$ & 1.58 & $1.03-2.42$ \\
\hline Remarried mothers & 151 & 1.37 & $0.92-2.05$ & 1.39 & $0.93-2.07$ & 1.29 & $0.85-1.96$ & 1.31 & $0.88-1.96$ & 1.23 & $0.81-1.89$ \\
\hline $\begin{array}{l}\text { Intermittent employed } \\
\text { married mothers } \\
\text { p value }\end{array}$ & 125 & $\begin{array}{l}1.51 \\
0.01 \\
\end{array}$ & $0.99-2.30$ & $\begin{array}{l}1.40 \\
0.03 \\
\end{array}$ & $0.91-2.15$ & $\begin{array}{l}1.59 \\
0.02 \\
\end{array}$ & $1.02-2.48$ & $\begin{array}{l}1.53 \\
0.02 \\
\end{array}$ & $1.00-2.35$ & $\begin{array}{l}1.54 \\
0.06 \\
\end{array}$ & $0.98-2.43$ \\
\hline \multicolumn{12}{|l|}{$\begin{array}{l}\text { Work quality (paid } \\
\text { and unpaid) age } 36\end{array}$} \\
\hline $\begin{array}{l}\text { Excellent } \\
\text { Good } \\
\text { Fair } \\
\text { Poor } \\
\text { Very poor } \\
\text { Missing } \\
\text { p value* }\end{array}$ & $\begin{array}{c}86 \\
220 \\
435 \\
182 \\
114 \\
134\end{array}$ & $\begin{array}{l}1.00 \\
0.89 \\
1.32 \\
1.17 \\
1.59 \\
1.04 \\
0.04 \\
\end{array}$ & $\begin{array}{l}0.51-1.55 \\
0.80-2.19 \\
0.67-2.05 \\
0.88-2.89 \\
0.57-1.88\end{array}$ & $\begin{array}{l}1.00 \\
0.87 \\
1.26 \\
1.12 \\
1.47 \\
0.97 \\
0.07 \\
\end{array}$ & $\begin{array}{l}0.50-1.52 \\
0.76-2.10 \\
0.64-1.96 \\
0.81-2.69 \\
0.53-1.76\end{array}$ & & & & & $\begin{array}{l}1.00 \\
0.85 \\
1.29 \\
1.24 \\
1.30 \\
1.07 \\
0.4 \\
\end{array}$ & $\begin{array}{l}0.47-1.53 \\
0.75-2.22 \\
0.68-2.27 \\
0.68-2.47 \\
0.57-2.02\end{array}$ \\
\hline \multicolumn{12}{|l|}{$\begin{array}{l}\text { Family and work } \\
\text { stress, ages } 48-54\end{array}$} \\
\hline $\begin{array}{l}\text { Lowest stress quintile } \\
2^{\text {nd }} \text { quintile } \\
3^{\text {rd }} \text { quintile } \\
4^{\text {th }} \text { quintile } \\
\text { Highest stress quintile } \\
\text { Missing }\end{array}$ & $\begin{array}{l}181 \\
199 \\
171 \\
170 \\
199 \\
251\end{array}$ & $\begin{array}{l}1.00 \\
1.67 \\
2.76 \\
3.02 \\
7.22 \\
5.90\end{array}$ & $\begin{array}{c}0.96-2.93 \\
1.59-4.77 \\
1.75-5.22 \\
4.30-12.11 \\
3.57-9.75\end{array}$ & & & $\begin{array}{l}1.00 \\
1.65 \\
2.83 \\
2.95 \\
7.21 \\
5.96\end{array}$ & $\begin{array}{c}0.94-2.90 \\
1.63-4.91 \\
1.70-5.10 \\
4.27-12.17 \\
3.59-9.89\end{array}$ & & & $\begin{array}{l}1.00 \\
1.65 \\
2.88 \\
3.12 \\
7.12 \\
5.80\end{array}$ & $\begin{array}{c}0.93-2.91 \\
1.65-5.02 \\
1.79-5.44 \\
4.19-12.11 \\
3.47-9.69\end{array}$ \\
\hline
\end{tabular}




\begin{tabular}{|l|c|c|l|r|r|r|}
$\mathrm{P}$ value* & & $<0.001$ & & $<0.001$ & \\
\hline Social class of head \\
of household age 43
\end{tabular}

${ }^{*}$ Excludes missings. 